\title{
Energy Analysis in Supermarkets
}

\section{Guilherme A. Carvalho ${ }^{\mathbf{1}}$, Michel Rohr ${ }^{\mathbf{1}}$, Paulo Cezar Bauer ${ }^{\mathbf{1}}$, Roberto Cesar Betini ${ }^{\mathbf{1}}$.} 'Universidade Tecnológica Federal do Paraná, Curitiba, Paraná, Brasil

\begin{abstract}
This study shows, through several analyses, ways to reduce costs with electric power in supermarkets. For this purpose, one of those establishments was visited and several data were collected for subsequent analysis. The results have shown that the combinations of several actions of energy efficiency can be applied when the objective is the reduction of costs with electric power.
\end{abstract}

Keywords: Energy efficiency, Analyses, Reduction of Tariff of Electric power, Supermarkets

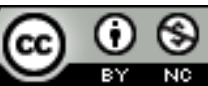

*Author of correspondence: gui_1991@hotmail.com 


\section{INTRODUCTION}

Starting from the extraordinary revision of the tariffs granted by ANEEL (National Agency of Electric power) and the beginning of the validity of the tariff flags in 2015, the price of the electric power suffered an expressive readjustment, with an increase of $51 \%$ in Paraná, just on that year. With that, the theme energy efficiency started to have strategic importance for companies' cost controls ${ }^{1}$.

In the sector of supermarkets, the use of the electric power is intensified due to air conditioning (systems of conditioned air), to the refrigerated spaces for conservation of foods that need such specification (cold cameras and freezers), and also to the high number of lamps that the installation needs, among others ${ }^{2}$.

The lighting of a supermarket represents $23 \%$ of the total consumption of energy, second only to the cooling system (38\%). Ventilation system equals to $15 \%$ of this consumption ${ }^{3}$.

Considering that the high bill for energy is a problem for the section of supermarkets. There is the need of accomplishing a study seeking measures of efficiency of energy and actions to be taken to turn the consumption of energy more efficient. And consequently, reducing the expenses of the company, and turning it more competitive. The focus of this work is on the lighting part, migration for the Energy Trading Market and actions that can be requested to the dealership of local energy.

\section{MATERIAL AND METHODS}

The first step is a visit to the premises to obtain several essential data for the preparation of the proposed studies, such as the schedule of operation of the analyzed plant, total area of the plant, installed power, lamps data collection.

Equally important is the access to the virtual agency of the energy distributor to which the establishment is connected, so that the data regarding the electric power bills and data of the digital meters of energy can be obtained. From the collection of the data the analyses begin and comparisons made.

\section{Collection of Data}

The supermarket of this study is located in the central area of Curitiba-PR. It has an area of approximately $1500 \mathrm{~m}^{2}$. Its schedule of operation is from $8 \mathrm{am}$ to $10 \mathrm{pm}$, from Monday to Saturday. On Sundays its schedule of operation is from $9 \mathrm{am}$ to $9 \mathrm{pm}$. This supermarket is part of a net of 3 other stores. Most of the present lighting is composed by 432 lamps with one light. Those lamps are of the tubular type of $54 \mathrm{~W}$ fluorescent and each one has a reactor of $6 \mathrm{~W}$. Measures were also made in the lightings with a device that measures the luminous incidence in Lux (Luximeter), to check whether their levels are in agreement with the Brazilian norm NBR ISO/CIE 8995-1:2013.

Through the invoices of electric power of the establishment it is observed that this is assisted by the local dealer (COPEL), and it has supply tension in $13,2 \mathrm{kV}$, in the green hourly tariff and with the measurement in low tension ${ }^{4}$.

Table 1 and Table 2 show the electric quantities invoiced in the last 12 months, and the amounts invoiced by the dealer. Also highlighted is the amount paid according to the current tariff flag for the invoiced month. 
Table 1 - Analysis of the billed data of 2015 (Jul / Dec).

Green Hourly Rate Table - Year 2015

\begin{tabular}{|c|c|c|c|c|c|c|c|c|c|c|c|c|c|}
\hline & & \multicolumn{5}{|c|}{ Demanda $(k W)$} & \multicolumn{2}{|c|}{ Consumo $(k W h)$} & \multirow[b]{2}{*}{$\begin{array}{l}\text { Load } \\
\text { Factor } \\
(\%)\end{array}$} & \multirow{2}{*}{$\begin{array}{c}\text { Unit } \\
\text { Cost } \\
(R \$ / k W h \\
)\end{array}$} & \multicolumn{2}{|c|}{ Custo (R\$/mês) } & \multirow[b]{2}{*}{ Comente } \\
\hline & & Contrato & Contract & Measure & $\begin{array}{c}\quad \text { Bil } \\
\text { Not } \\
\text { Used } \\
\end{array}$ & $\begin{array}{l}\text { led } \\
\text { Used }\end{array}$ & $\begin{array}{l}\text { Reactive } \\
\text { Sumpluss }\end{array}$ & Measure & & & Partial & $\begin{array}{l}\text { Custo } \\
\text { Total }\end{array}$ & \\
\hline \multirow{2}{*}{ 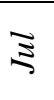 } & Out & \multirow{2}{*}{230} & 229.46 & \multirow{2}{*}{0.54} & 229 & \multirow{2}{*}{0.00} & 95766 & 380 & 62.85 & 0.5936 & 56850.02 & \multirow{2}{*}{57881.17} & Red Flag \\
\hline & Peak & & 140.52 & & .46 & & 659 & 1 & 7.11 & 1.5647 & 1031.15 & & $R \$ 8158.68$ \\
\hline \multirow{2}{*}{$\stackrel{\infty}{<}$} & Out & \multirow{2}{*}{230} & 223.17 & \multirow{2}{*}{6.83} & 223 & \multirow{2}{*}{0.00} & 98475 & 159 & 66.45 & 0.6394 & 62967.55 & \multirow{2}{*}{64299.98} & Red Flag \\
\hline & Peak & & 162.75 & & .17 & & 788 & 0 & 7.34 & 1.6909 & 1332.42 & & $R \$ 8382.28$ \\
\hline \multirow{2}{*}{$\stackrel{\varpi}{\varpi}$} & Out & \multirow{2}{*}{230} & 223.17 & \multirow{2}{*}{6.83} & 223 & \multirow{2}{*}{0.00} & 94642 & 82 & 63.87 & 0.6297 & 59599.52 & \multirow{2}{*}{61584.48} & Red Flag \\
\hline & Peak & & 175.94 & & .17 & & 1191 & 0 & 10.26 & 1.6666 & 1984.96 & & $R \$ 7798.55$ \\
\hline \multirow{2}{*}{$\Xi$} & Out & \multirow{2}{*}{230} & 234.78 & \multirow{2}{*}{0.00} & 234 & \multirow{2}{*}{0.00} & 93185 & 63 & 59.77 & 0.6176 & 57554.45 & \multirow{2}{*}{59176.47} & Yellow Flag \\
\hline & Peak & & 174.52 & & .78 & & 981 & 0 & 8.52 & 1.6534 & 1622.02 & & $R \$ 6420.40$ \\
\hline \multirow{2}{*}{$\vec{z}^{\vec{z}}$} & Out & \multirow{2}{*}{230} & 246.59 & \multirow{2}{*}{0.00} & 246 & \multirow{2}{*}{0.00} & 102670 & 16 & 62.70 & 0.6222 & 63877.01 & \multirow{2}{*}{0.00} & Green Flag \\
\hline & Peak & & 1.00 & & .59 & & 32 & 0 & 48.48 & 1.6600 & 53.12 & & $R \$ 7032.12$ \\
\hline \multirow{2}{*}{ 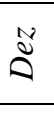 } & Out & \multirow{2}{*}{230} & 241.67 & \multirow{2}{*}{0.00} & 241 & & 98185 & 0 & 61.19 & 0.6405 & 62888.14 & & Green Flag \\
\hline & Peak & & 1.00 & & .67 & 0.00 & 0 & 0 & 0.15 & 0.6105 & 0.06 & 32508.84 & $R \$ 6925.27$ \\
\hline$\frac{8}{2}$ & Out & 230 & 233 & & & & 97154 & 117 & 62.76 & 0.6238 & 60622.78 & & \\
\hline 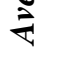 & Peak & & 109 & 2 & 233 & 0 & 609 & 0 & 8.44 & 1.4744 & 1003.96 & 61626.74 & \\
\hline
\end{tabular}


Table 2 - Analysis of the billed data of 2016 (Jan / Jul).

Green Hourly Rate Table - Year 2016

\begin{tabular}{|c|c|c|c|c|c|c|c|c|c|c|c|c|c|}
\hline & & \multicolumn{5}{|c|}{ Demanda $(k W)$} & \multicolumn{2}{|c|}{ Consumo $(k W h)$} & \multirow[b]{2}{*}{$\begin{array}{c}\text { Load } \\
\text { Factor } \\
(\%)\end{array}$} & \multirow[b]{2}{*}{$\begin{array}{l}\text { Unit Cost } \\
(R \$ / k W h)\end{array}$} & \multicolumn{2}{|c|}{ Custo (R\$/mês) } & \multirow[b]{2}{*}{ Coments } \\
\hline & & Contract & Measure & $\begin{array}{l}\quad B i \\
\text { Not } \\
\text { Used } \\
\end{array}$ & $\begin{array}{l}\text { lled } \\
\qquad \text { Used }\end{array}$ & $\begin{array}{l}\text { Reactive } \\
\text { Sumpluss }\end{array}$ & Measure & $\begin{array}{l}\text { Reactive } \\
\text { Sumpluss }\end{array}$ & & & Partial & Total Cost & \\
\hline \multirow{2}{*}{$\Xi$} & Out & \multirow{2}{*}{230} & 258.79 & \multirow{2}{*}{0.00} & \multirow{2}{*}{258.79} & \multirow{2}{*}{0.00} & 104410 & 8 & 60.76 & 0.6451 & 67357.26 & \multirow{2}{*}{67357.26} & Red Flag \\
\hline & Peak & & 0.00 & & & & 0 & 0 & 0.00 & 0.0000 & 0.00 & & $R \$ 7374.79$ \\
\hline \multirow{2}{*}{ एे } & Out & \multirow{2}{*}{230} & 247.77 & \multirow{2}{*}{0.00} & \multirow{2}{*}{247.77} & \multirow{2}{*}{0.00} & 105353 & 3 & 64.04 & 0.6445 & 67902.39 & \multirow{2}{*}{67902.39} & Red Flag \\
\hline & Peak & & 0.00 & & & & 0 & 0 & 0.00 & 0.0000 & 0.00 & & $R \$ 7190.12$ \\
\hline \multirow{2}{*}{ 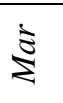 } & Out & \multirow{2}{*}{230} & 246.98 & \multirow{2}{*}{0.00} & \multirow{2}{*}{246.98} & \multirow{2}{*}{0.00} & 98382 & 0 & 59.99 & 0.6217 & 61166.95 & \multirow{2}{*}{61183.93} & Red Flag \\
\hline & Peak & & 0.00 & & & & 10 & 0 & 0.00 & 1.6982 & 16.98 & & $R \$ 4028.39$ \\
\hline \multirow{2}{*}{$\frac{\grave{k}}{\bar{k}}$} & Out & \multirow{2}{*}{230} & 235.17 & \multirow{2}{*}{0.00} & \multirow{2}{*}{235.17} & \multirow{2}{*}{0.00} & 98104 & 0 & 62.83 & 0.5885 & 57730.30 & \multirow{2}{*}{57909.95} & Yellow Flag \\
\hline & Peak & & 0.00 & & & & 108 & 0 & 0.00 & 1.6634 & 179.65 & & $R \$ 2015.02$ \\
\hline \multirow{2}{*}{$\vec{z}$} & Out & \multirow{2}{*}{230} & 232.61 & \multirow{2}{*}{0.00} & 23261 & 000 & 97539 & 7 & 63.15 & 0.5632 & 54937.03 & 5534118 & Green Flag \\
\hline & Peak & & 57.22 & & 232.01 & 0.00 & 248 & 0 & 6.57 & 1.6296 & 404.15 & 5341.18 & $R \$ 0.00$ \\
\hline$\cong$ & Out & 230 & 200.73 & 2027 & 20073 & $0 \Omega$ & 91675 & 0 & 68.78 & 0.5628 & 51599.08 & & Green Flag \\
\hline 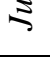 & Peak & 230 & 84.67 & 29.27 & 200.73 & 0.00 & 385 & 0 & 6.89 & 1.6277 & 626.67 & 52225.75 & $R \$ 0.00$ \\
\hline$\approx$ & Out & & 205.45 & & & & 86202 & 0 & 63.19 & 0.5281 & 45522.08 & & Green Flag \\
\hline$\stackrel{5}{5}$ & Peak & 230 & 151.49 & 24.55 & 205.45 & 0.00 & 664 & 0 & 6.64 & 1.6078 & 1067.56 & 46589.64 & $R \$ 0.00$ \\
\hline & Out & 230 & 233 & 8 & 233 & 0 & 97381 & 3 & 63.08 & 0.5934 & 58030.73 & 5835859 & \\
\hline & Peak & 230 & 42 & 8 & 233 & 0 & 202 & 0 & 7.31 & 1.1752 & 327.86 & 58358.59 & \\
\hline
\end{tabular}


We can observe from the data of consumption that demand exceeded in the months before the summer and also in the summer months. Because the temperatures are usually higher and there is a larger use of cooling equipment. In the case of a supermarket, there is an increase of the use of the system of air conditioning, as well as the use of freezers and refrigerators. At this time of the year there is a larger search for cold drinks, frozen and ice creams.

It can also be observed that consumption at peak times is practically zero. In other words, this supermarket uses a generator at peak hours to reduce costs at this time, which in the Green Hour Rate is very high in relation to the out of peak tariff.

It is possible to visualize the use of reactive energy, a consequence of low power factor, less than $92 \%$.

That just happened in some months (Jul. to Nov.) 2015. To solve this situation it is recommended to install a capacitor bank or just adjust the time controller, which may be entering the wrong time. In 2016, this problem practically didn't happen, due to the maintenance and/or correct installation of the amount of necessary capacitors.

\section{RESULTS AND DISCUSSION}

With the data of the mass memory obtained from the virtual agency of the dealership, a graph of the measured demand was created every 15 minutes, presented in Figure 1.

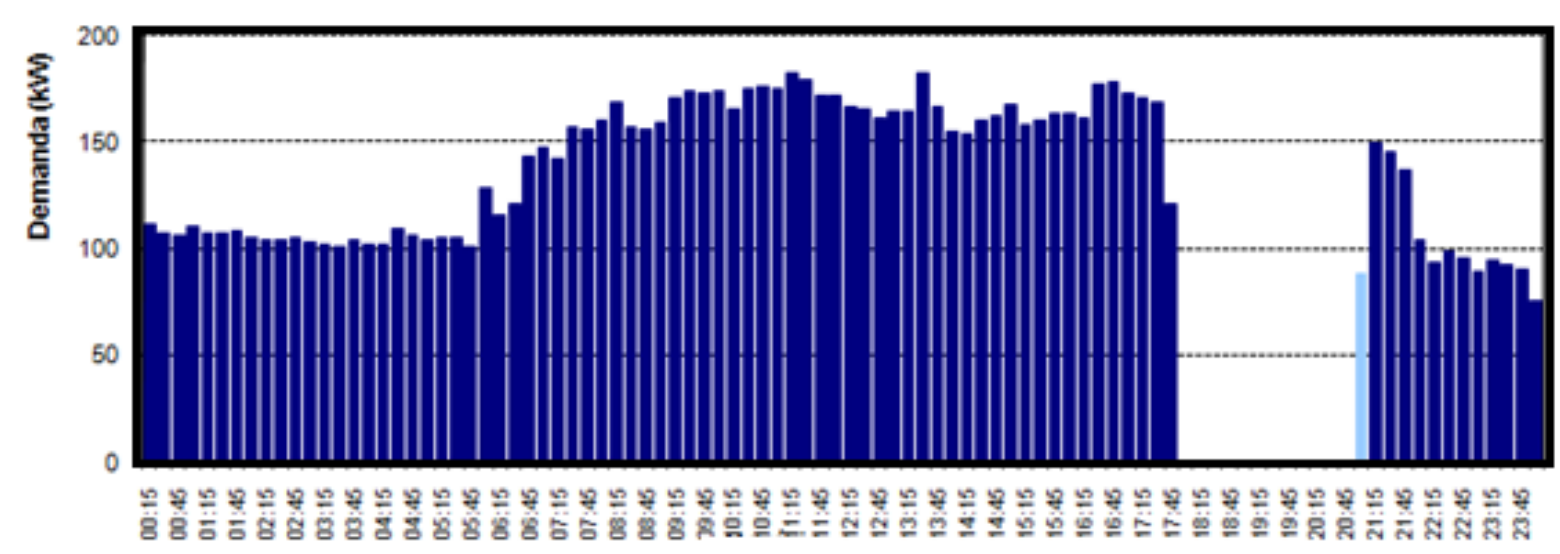

Figure 1 - Graph of Demand.

In Figure 1 we can see that there is no demand data at a particular time, which corresponds to peak hours (usually 3 consecutive hours from 6:00 p.m. to 9:00 p.m.), since we can confirm that the supermarket is using a generator to supply energy at this time.

\section{Study of Economy with the Best Tariff Framework}

For the choice of the best tariff option, a spreadsheet that calculates the monthly cost for the two tariff options: green or blue (Table 3) was used. In Table 3, the demand and the active and reactive consumption are input data. And the output data are the monthly cost in Real (R\$) and the cost for MWh (R $\$ / M W h)$.

Some premises were adopted in the completion of the spreadsheet. Firstly in the line (A) we have the contracted demand in the peak being equal to out of peak. In (B) we have something similar where the measured demand in the peak was considered as equal to out of peak. Another measure adopted in the line (C) was considered for the 
consumption of peak as being $17.16 \%$ of the consumption out of peak, as data obtained through the analyzer of energy. That consumption cannot be observed in the energy bills due to the fact that Supermarket "A" uses generator in the period of peak. In the columns "Green Tariff" and "Blue Tariff" are the value in Real (R\$) for each portion of the calculation. And in line (D), we have the final result that is the sum of those portions and the final value of the cost of energy for the two tariff options.

Finally, the used taxes were PIS 1\%, COFINS 4,7\% and ICMS 29\%, together with the updated tariffs concerning homologation resolution number $2,096^{5}$.

Table 3 - Tariff Option.

Rate Comparative Green Tariff

Blue Tariff

\begin{tabular}{|c|c|c|c|c|c|c|c|}
\hline \multirow{6}{*}{ 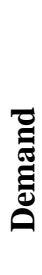 } & \multirow{7}{*}{ (a) } & \multicolumn{2}{|c|}{ Contract $(\mathrm{kW})$} & \multicolumn{2}{|c|}{ Billed (not used) } & \multicolumn{2}{|c|}{ Billed (not used) } \\
\hline & & & Peak & & Peak & & \\
\hline & & Out & Time & Out & Time & Out & Peak Time \\
\hline & & 230 & 230 & 0,00 & 0 & 0,00 & 0,00 \\
\hline & & \multicolumn{2}{|c|}{ Mesure (kW) } & \multicolumn{2}{|c|}{ Billed } & \multicolumn{2}{|c|}{ Billed } \\
\hline & & & Peak & & Peak & & \\
\hline & & Out & Time & Out & Time & Out & Peak Time \\
\hline \multirow{7}{*}{ نُ } & \multirow[t]{2}{*}{ (b) } & 241,67 & 241,67 & $4.318,68$ & 0 & $4.318,68$ & $10.800,79$ \\
\hline & & Activ & $(\mathrm{kWh})$ & \multicolumn{2}{|c|}{ Billed } & \multicolumn{2}{|c|}{ Billed } \\
\hline & \multirow{5}{*}{ (c) } & Out & $\begin{array}{l}\text { Peak } \\
\text { Time }\end{array}$ & Out & $\begin{array}{l}\text { Peak } \\
\text { Time }\end{array}$ & Out & Peak Time \\
\hline & & 98185 & 9818,5 & $42.319,55$ & $15.714,45$ & $42.319,55$ & $6.012,77$ \\
\hline & & \multicolumn{2}{|c|}{ Reactive Sumplus } & \multicolumn{2}{|c|}{ Billed } & \multicolumn{2}{|c|}{ Billed } \\
\hline & & & Peak & \multicolumn{2}{|r|}{ Peak } & \multirow{2}{*}{\multicolumn{2}{|c|}{ Peak Time }} \\
\hline & & Out & Time & Out & Time & & \\
\hline \multirow{6}{*}{$\overrightarrow{\tilde{y}}$} & \multirow{6}{*}{ (d) } & 0 & 0 & 0,00 & 0 & 0,00 & 0 \\
\hline & & \multicolumn{2}{|c|}{ TOTAL } & $\mathbf{R} \$$ & $62.352,68$ & $\mathbf{R} \$$ & $63.451,80$ \\
\hline & & \multicolumn{2}{|c|}{$\begin{array}{c}\text { Average Price } \\
\text { (R\$/MWh) }\end{array}$} & \multicolumn{2}{|c|}{577,32} & \multicolumn{2}{|c|}{587,50} \\
\hline & & \multirow{3}{*}{\multicolumn{2}{|c|}{ Load Factor }} & & Peak & & \\
\hline & & & & Out & Time & Out & Peak Time \\
\hline & & & & $61 \%$ & $62 \%$ & $61 \%$ & $62 \%$ \\
\hline
\end{tabular}

Through Table 3 a monthly simulation in a period of one year was performed, to check which option would give the lowest cost. Table 4 shows the results of these simulations.

Table 4 - Comparative Results between Green Tariff and Blue Tariff.

\begin{tabular}{|c|c|c|}
\hline Month & Green Tariff & Blue Tariff \\
\hline jul/15 & $\mathrm{R} \$ 72.643,59$ & $\mathrm{R} \$ 65.291,38$ \\
\hline aug/15 & $\mathrm{R} \$ 69.959,49$ & $\mathrm{R} \$ 63.252,22$ \\
\hline sep/15 & $\mathrm{R} \$ 69.050,48$ & $\mathrm{R} \$ 62.866,64$ \\
\hline oct $/ 15$ & $\mathrm{R} \$ 76.420,00$ & $\mathrm{R} \$ 70.459,80$ \\
\hline nov/15 & $\mathrm{R} \$ 73.040,64$ & $\mathrm{R} \$ 67.238,13$ \\
\hline $\mathrm{dez} / 15$ & $\mathrm{R} \$ 78.230,33$ & $\mathrm{R} \$ 73.457,61$ \\
\hline jan/16 & $\mathrm{R} \$ 78.356,05$ & $\mathrm{R} \$ 72.087,57$ \\
\hline fev/16 & $\mathrm{R} \$ 73.436,21$ & $\mathrm{R} \$ 68.244,82$ \\
\hline $\operatorname{mar} / 16$ & $\mathrm{R} \$ 72.501,36$ & $\mathrm{R} \$ 65.505,63$ \\
\hline apr/18 & $\mathrm{R} \$ 72.064,32$ & $\mathrm{R} \$ 65.060,11$ \\
\hline may/16 & $\mathrm{R} \$ 67.770,22$ & $\mathrm{R} \$ 61.283,08$ \\
\hline jun/16 & $\mathrm{R} \$ 63.961,17$ & $\mathrm{R} \$ 58.453,62$ \\
\hline Total: & $\mathrm{R} \$ \mathrm{867.433,86}$ & R\$ 793.200,61 \\
\hline \multicolumn{2}{|c|}{ Best Rate Option } & Blue Tariff \\
\hline \multicolumn{2}{|c|}{ Anual Savings } & $\begin{array}{c}\mathbf{8 , 5 6 \%} \\
\text { R\$ 74.233,25 }\end{array}$ \\
\hline
\end{tabular}


It can be observed at the end of Table 4 the annual economy, that it is the sum of the costs of the simulation in the period of one year. The best tariff option for the Supermarket "A" is the blue tariff, that gives a total amount of $\mathrm{R} \$ 74,233.25$ less in one year in relation to the green tariff.

\section{Study of Economy with Implantation of Led Lamps}

The period of Payback is the time that a project takes to pay itself. It is one of the simplest procedures to obtain an estimate of time of return and it is very much used by companies, for presenting options of projects in which the invested capital returns as soon as possible.

The monthly economy obtained by the implantation of the lighting using LEDs is given by (1).

$$
\begin{gathered}
\text { Economy }=(\text { R. C. Fluorescent Lamp. + C. E. E. Fluorescent Lamp. }) \\
-(\text { R. C. LED + C. E. E. LED })
\end{gathered}
$$

Where R.C. $=$ Monthly Replacement Cost and C.E.E. $=$ Monthly Cost of Electrical Energy.

In this study, it is proposed the replacement of 432 fluorescent lamps (T5 - 1200mm), with potency of $54 \mathrm{~W}+6 \mathrm{~W}$ of the reactor. And with installed total potency of 25.92 $\mathrm{kW}$, daily operation of 14 hours (22 days of peak and 30 days out of peak) and monthly total consumption of $10,265.32 \mathrm{kWh}$.

The proposal is to use lamps of LED of $30 \mathrm{~W}$ to replace the fluorescent lamps of 54 $\mathrm{W}$. The new installed total potency would be $12.96 \mathrm{~kW}$ and it would have a monthly total consumption of $5,132.16 \mathrm{kWh}$.

The value of the tariff paid by the Supermarket "A" in the period of peak is $\mathrm{R} \$ 1.6078$ / $\mathrm{kWh}$ and out of peak it is R $\$ 0.5281 / \mathrm{kWh}$ (as for 07/2016 plus taxes). These data were obtained from the unit cost of the hourly rate green peak and out of peak. Therefore, with this action the obtained monthly economy would be $\mathrm{R} \$ 4.034,15$. The payback of the system can be expressed by (2):

$$
\text { Payback }=\frac{\text { Total cost of implantation }}{\text { Monthly Economy }}
$$

The cost of each one of the LED lamps is of $\mathrm{R} \$ 79.90$. The cost of labor for the installation is $\mathrm{R} \$ 15.00$ per lamp. And the cost of discard of the old lamps is $\mathrm{R} \$ 0.60$ per lamp, totaling a cost of implantation $\mathrm{R} \$ 41,256.00$. Therefore, it is considered that the payback of the lighting system using LED lamps is approximately 10.2 months.

\section{Study of Economy with the Migration to the Energy Trading Market}

From January 2015 to July 2016, the amount of free consumers increased $81 \%$. Considering the migrations already programmed for the next semester, the quantity of free consumers should reach a total greater than 3.220 until the end of 2016. With this scenery, the Energy Trading Market of energy receives, on average, 100 new customers a month. In this situation, the number of companies that negotiate their own energy should double by the end of 2017 , estimates ${ }^{6}$.

The decrease in the price of the energy is the great reason of the increase of migration of the companies, but it is not the only one. The free consumer starts to negotiate supply contracts directly with energy generators or traders, with price, period and indexes of readjustment previously set, explains Mr. Cristopher Vlavianos, president of Comerc. This gives predictability of cost to the consumer, who already knows how 
much s/he will pay for energy during the term of the contract, without surprises at the end of the month ${ }^{6}$.

In view of this attractive scenario, a study was carried out for Supermarket "A", which shows what its economy would be if it joined the Free Energy Market.

Companies with equal or demand to $500 \mathrm{~kW}$, per unit or with the sum of units with same CNPJ, can acquire energy generated by renewable sources, such as hydroelectric power stations of small size (SHPs), thermoelectric plants that use biomass, wind power sources, among others. As the sum of the three units of this supermarket chain corresponds to $530 \mathrm{~kW}$, these can fit as special consumers.

Because it is a special consumer (demand between $500 \mathrm{~kW}$ and $3,000 \mathrm{~kW}$ ) and consumes energy from alternative sources, this type of profile receives a 50\% discount on the TUSD (Tariff for Use of Electric Distribution Systems).

The total consumption of this unit was made based on the average of the last 12 months of billing recorded by the dealer. For consumption at the peak, as Supermarket "A" uses a generator, we use a value of $17.16 \%$ of consumption out of peak.

As the purchase of the energy in the Energy Trading Market is made through MWm (average Megawatt), the average Megawatt was calculated considering the total consumption (Out of Peak + Peak) in MWh and divided by the medium number of hours in one month ( 730 hours). The value of $0.1646 \mathrm{MWm}$ was obtained. This value is very important to know the necessary amount to contract energy from generators or energy traders in possible auctions.

In the simulations, it was decided to adopt a value of $0.16 \mathrm{MWm}$ due to the fact that energy traders adopt flexibility limits in contracting energy, with average values of $20 \%$ either for more or less, thus making the value chosen for the Simulations sufficient to supply the consumption of Supermarket "A" and this consumption is within the flexibility. Also, 3\% of generation losses were considered. This value is standardized, taking the total of the consumption (peak + out of peak) and increasing $3 \%$. Table 5 displays a summary of the data used in the calculations of the Energy Trading Market.

Table 5 - Data for simulation in the Energy Trading Market.

Supermarket "A"

\begin{tabular}{cc}
\hline Concessionaire & Copel \\
\hline Subgroup & A4 \\
\hline Current Rate & Green \\
\hline Energy Traiding Market & Blue \\
\hline Type of Energy & Encouraged \\
\hline Discount on TUSD & $50 \%$ \\
\hline MWm & 0,16 \\
\hline Generation Loss & $3 \%$ \\
\hline Peak Consuption $(\mathrm{kWh})$ & 16.693 \\
\hline Out of Peak Consuption $(\mathrm{kWh})$ & 97.276 \\
\hline Demand $(\mathrm{KW})$ & 240 \\
\hline
\end{tabular}


Table 6 was used for the calculation of the migration viability to the Energy Trading Market of energy, admitting the data of the Table 5 as input data to make calculations and to comparing the captive market with the Energy Trading Market.

Table 6 displays how the calculation of the values of the Energy Trading Market is made, indicating separately the values of the distribution and of the generation which have their own tariffs.

Table 7 compares the different prices of the energy in the Energy Trading Market. We can observe that the value of the captive market remains always the same as the tariff of use of the system and the tariff of energy have fixed prices, according to homologation resolution $n^{\circ}$ 2,096. The value of the Energy Trading Market, on the other hand, depends on the value of the contracted energy.

With the values of energy used in the simulation (from $\mathrm{R} \$ 150.00 / \mathrm{MWh}$ to $\mathrm{R} \$$ $250.00 / \mathrm{MWh}$ ), it is possible to have an idea of the percentage of possible economy after the migration to the Energy Trading Market.

In Table 7, the line where the value 210 is found, corresponds to the price $\mathrm{R} \$ / \mathrm{MWh}$ of the energy. It is highlighted because it is exactly the value used in the example of Table 6. In Table 6 the value 0.21 appears circled, and this corresponds to the transformation of $210 \mathrm{R} \$ / \mathrm{MWh}$ in $0.21 \mathrm{R} \$ / \mathrm{kWh}$, due to the fact that the data of the consumption are all in $\mathrm{kWh}$. To complete Table 6 , the variation of these values from 0.15 up to 0.25 was calculated, corresponding to $150 \mathrm{R} \$ / \mathrm{MWh}$ up to $250 \mathrm{R} \$ / \mathrm{MWh}$, and transferred to Table 7.

For the company to enter the Energy Trading Market of Energy, it is necessary to communicate Copel, with at least 180 days before the expiration of the energy supply agreement, that the client does not want the automatic renewal. It is also necessary the adaptation of the metering and billing system to the standards required by CCEE (Electric Energy Trading Chamber).

Table 6 - Blue Captive Market x Blue Energy Trading Market.

Captive Market - Blue

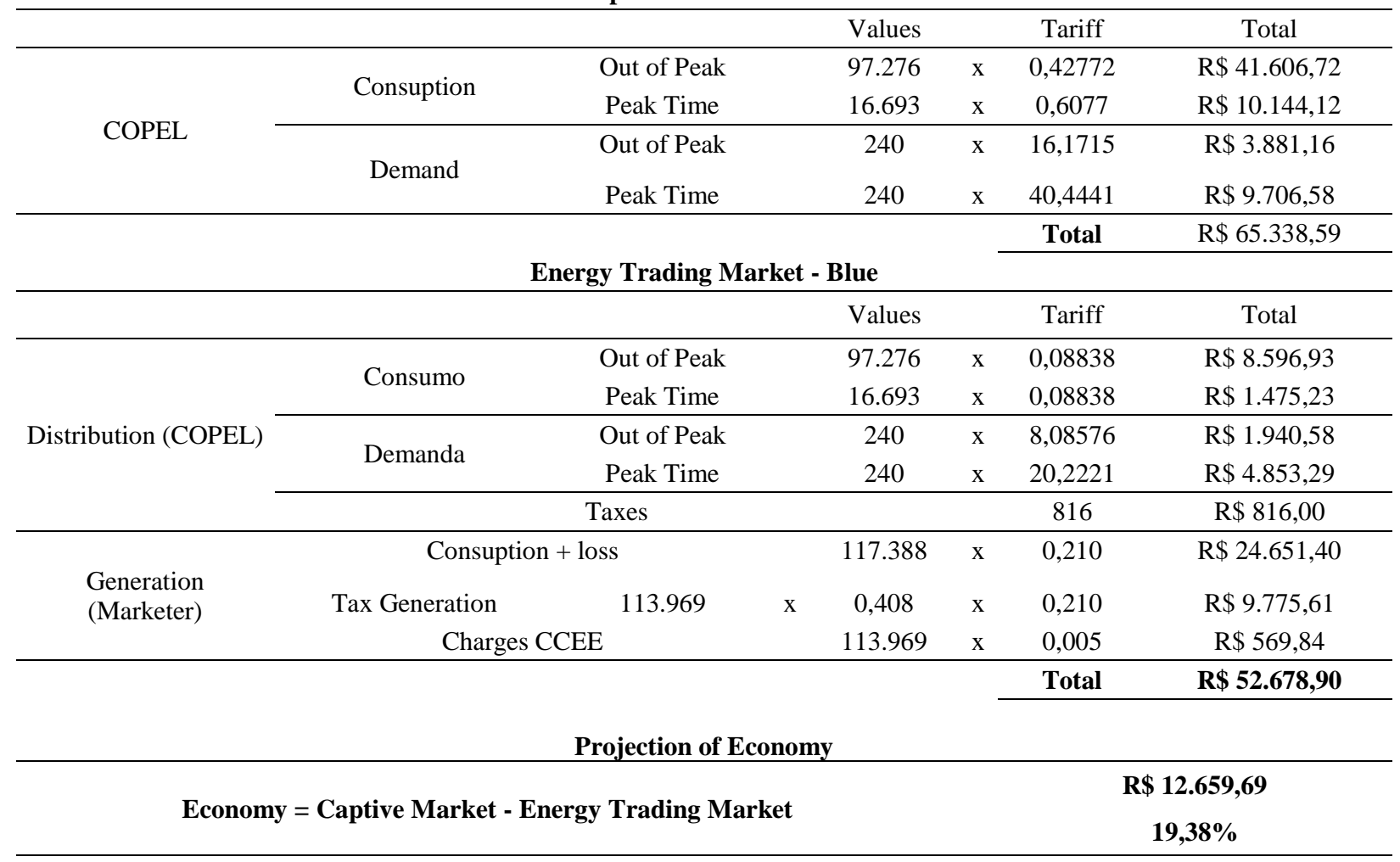


Table 7 - Obtained economy varying the prices of the energy in the Energy Trading Market.

\begin{tabular}{ccccc} 
Price R\$MWh & Captive $(\mathrm{R} \$)$ & $\begin{array}{c}\text { Energy Trading Market } \\
(\mathrm{R} \$)\end{array}$ & \multicolumn{2}{c}{ Economy } \\
\hline 150 & $65.338,59$ & $42.842,61$ & $22.495,98$ & $34,43 \%$ \\
160 & $65.338,59$ & $44.481,99$ & $20.856,59$ & $31,92 \%$ \\
170 & $65.338,59$ & $46.121,37$ & $19.217,21$ & $29,41 \%$ \\
180 & $65.338,59$ & $47.760,75$ & $17.577,83$ & $26,90 \%$ \\
190 & $65.338,59$ & $49.400,13$ & $15.938,45$ & $24,39 \%$ \\
200 & $65.338,59$ & $51.039,52$ & $14.299,07$ & $21,88 \%$ \\
210 & $65.338,59$ & $52.678,90$ & $12.659,69$ & $19,38 \%$ \\
220 & $65.338,59$ & $54.318,28$ & $11.020,31$ & $16,87 \%$ \\
230 & $65.338,59$ & $55.957,66$ & $9.380,92$ & $14,36 \%$ \\
240 & $65.338,59$ & $57.597,04$ & $7.741,54$ & $11,85 \%$ \\
250 & $65.338,59$ & $59.236,42$ & $6.102,16$ & $9,34 \%$ \\
\hline
\end{tabular}

\section{CONCLUSIONS}

This research was carried out in several stages. The first step was to carry out a survey of the data of Supermarket "A", so that visits to the installation and measurements in the place and consultation in the virtual system of the concessionaire were allowed. With the data collected we were able to carry out the various studies presented.

The analyzes of the electric energy bills showed that there were several overtakes in demand, so a study was carried out which indicated the ideal demand to be contracted, of $237 \mathrm{~kW}$, projecting the costs with this new demand an annual saving of $\mathrm{R} \$$ $1,868.70$ can be obtained. Also, through the invoice analysis data, a tariff study was carried out, in order to choose the best rate modality. This study showed that the blue modality is the most appropriate to the "A" Supermarket. At the end of this stage, the annual savings of $\mathrm{R} \$ 74,233.25$ were presented, representing a difference of $8.56 \%$ of the blue tariff compared to the green tariff.

In another tariff approach, the feasibility study of migration to the free energy market was carried out. The results showed a monthly saving, depending on the value of the energy purchased. In financial terms this represents amounts ranging from $9.34 \%$ to $34.43 \%$ of the current electricity bill.

With the data collection and the simulation of the "A" Supermarket lighting system, it was evidenced that substitutions can be made for the 432 current $54 \mathrm{~W}$ fluorescent lamps with $30 \mathrm{~W}$ LED bulbs. This change would bring a monthly economy of $\mathrm{R} \$$ $4,034.15$. With the aim of knowing the time of return of the investment, in case that substitution is accomplished, we reached the conclusion that the payback is approximately 10.2 months.

The values mentioned in the text above are summarized in Table 8 . The total sums projected for a month and a year are also displayed. 
Table 8 - Summary of Savings.

\begin{tabular}{cc} 
Economy: & Value: \\
\hline Demand Ajustement (Yearly) & $\mathrm{R} \$ 1.868,70$ \\
Change to Blue Rate (Yearly) & $\mathrm{R} \$ 74.233,25$ \\
Energy Trading Market (Monthly) & $\mathrm{R} \$ 12.659,69$ \\
Light Switch (Monthly) & $\mathrm{R} \$ 4.034,15$ \\
\hline Total (Monthly) & $\mathrm{R} \$ 23.035,67$ \\
\hline Total (Yearly) & $\mathrm{R} \$ 276.428,03$
\end{tabular}

Table 9 shows the simulation of the results before and after making the adjustments mentioned in the course of this work, projected for one month.

Table 9 - Results of Simulation.

Results of Simulation

\begin{tabular}{lr}
\multicolumn{2}{c}{ Results of Simulation } \\
\hline Total Paid (Avarage of the last 12 months) & $\mathrm{R} \$ 60.032,44$ \\
\hline Total Paid (Adjustment cited) & $\mathrm{R} \$ 43.182,87$ \\
\hline Total (Monthly) & $\mathrm{R} \$ 16.849,57$ \\
\hline & $28,07 \%$ \\
\cline { 2 - 2 }
\end{tabular}

Finally, we can conclude that there are different ways of achieving savings and improving energy efficiency in a supermarket. Some actions do not require financial investment, as is the case of contracting demand and choosing the rate option. But others require an initial investment, which is paid over time, as was shown in the work with the study of lamp replacement. Thus, what should be done is the combination of the greatest number of possible actions to minimize costs and increase energy efficiency.

\section{REFERENCES}

1. Fernando Jasper. Conta de luz no Paraná já subiu $51 \%$ neste ano Disponível em: <http://www.gazetadopovo.com.br/economia/conta-de-luz-no-parana-ja-subiu-51-nesteano-b8qkz4gt4tdlpa64uzjv4o5uc>. Acesso em: 19 set. 2015.

2. José A. Barros Oliveira. Estudo de Eficiência Energética na Refrigeração de um Supermercado. Universidade de Aveiro 2012.

3. P. H. S. Souza. Custo de Energia passa a ser $2^{a}$ maior despesa de um supermercado: saiba como economizar. 21 de janeiro de 2016. Disponível em: http://www.linkedin.com/pulse/custo-de-energia-passa-ser-2a-maior-despesa-um-saibasilva-de-souza?forceNoSplash=true>. Acesso em: 13 set. 2016.

4. Companhia Paranaense de Energia - COPEL. Agência Virtual Copel. Disponível em: $<$ https://agencia.copel.com/AgenciaWeb /autenticar /loginCliente.do;jsessionid=5207D556F373C5E755FD251441AB0952. node2>.

5. Companhia Paranaense de Energia - COPEL. Tributos Copel. Disponível em: <http://www.copel.com/hpcopel/root/nive 12.jsp?endereco $=\% 2$ Fhpcopel $\% 2$ Froot $\% 2$ Fpagcopel2.nsf $\% 2$ Fdocs $\% 2 F 3 E E 1 D 015 F A 3 F 43$ 3203257EE6003E128E>. Acesso em: 18 jul. 2016.

6. Cintia Junges. Pequenas e médias empresas trocam concessionárias por mercado livre de energia. Disponível em: <http://www.gazetadopovo.com.br/economia/energia-esustentabilidade/pequenas-e-medias-empresas-trocam-concessionarias-por-mercado-livrede-energia4d72hk2ju hzyukxjk7kerlgnt>. Acesso em: 22 jul. 2016. 